\title{
San Agustín y el placer del acto sexual matrimonial
}

JosÉ Ma Mora MonTeS

\section{INTRODUCCIÓN}

Este estudio se circunscribe al anunciado bíblico: "No es bueno que el hombre esté solo; démosle una compañera semejante a él" (Génesis 2,18)

S. Agustín, reconocido como uno de los principales doctores y padres de la Iglesia, gran filósofo y teólogo, que supo conciliar los dogmas cristianos con la filosofía platónica, es también una figura reconocida por su inteligencia psicológica y capacidad de introspección, que escribe en clave fenomenológica y existencial con gran aproximación a los tiempos actuales. Son muchos los conceptos agustinianos que han transcendido al paso del tiempo y mantienen su vigencia, sirva de ejemplo, su teoría de la iluminación, según la cual el hombre no puede conocer la verdad inmutable de las cosas a menos que su mente, a semejanza de la luz del Sol que ilumina las cosas, esté iluminada por la luz de Dios.

El ensayo presente se centra en unos conceptos del obispo de Hipona que actualmente se silencian porque no concuerdan, desafinan, casi provocan vergüenza, se podría decir, con los aires de los tiempos actuales, que dentro y fuera de la Iglesia Católica, están muy distantes de los que durante siglos han imperado en el occidente europeo. La ética moral agustiniana, en lo relativo a la sexualidad, afirman muchos teólogos, entra de lleno en un tipo rigorista, reductivo, muy negativo, que ha conducido a 
hombres y mujeres a llevar una vida triste y sacrificada, que de algún modo la Iglesia habría de arrepentirse y pedir perdón.

Es una realidad sociológica que el placer sexual estuvo estrictamente racionado y sometido a la carga de lo malo y pecaminoso que arrastraría todo aquel que se arriesgara a sobrepasar el límite de lo permitido. En aparatoso contraste, a mediados del pasado siglo, especialmente tras el mayo francés del 68, un vuelco sin precedentes se produce en la consideración del placer de la carne por parte de la masa social. Desaparecen todos los diques de contención y se proclama a los cuatro vientos y sin rubor que todo placer sexual, cualquier tipo sin excepción alguna, no solo es lícito sino que hay que cultivar. El hombre actual centra su interés en alcanzar la felicidad en este mundo y no se resigna a renunciar a los placeres que se le ofrecen y se solaza especialmente en el más cercano y asequible que tiene: el de su propia sexualidad, sin importarle un ardite la orientación que esta toma.

Este viraje en la conducta de los pueblos ha colocado el placer sexual en el epicentro de un nuevo debate en torno a su naturaleza psicológica y entidad ética, sobre el que se mantiene la natural cautela para aquilatarlo. Obviamente, el problema del acto sexual conyugal en su aspecto moral es competencia de la Teología Moral y se elude en este trabajo de forma concluyente. Pero hay varios conceptos agustinianos que han sido censurados desde hace varios decenios por resoluciones posconciliares y son dignos de reflexión. De tal forma, resulta chocante el antagonismo entre la idea del "mal permitido" y la afirmación "de ser el acto sexual honesto y digno", y esta otra, de ser un acto "vergonzoso", enfrentado a "una expresión de amor".

La crítica a los mencionados postulados del obispo de Hipona debe ser contemplada como una nueva postura eclesial ante la sexualidad, ahora más positiva, comprensiva, abierta, que en tiempos pasados, pero, ¿acaso no es también un viraje, difícilmente comprensible para cualquier católico, de los criterios tradicionales para no disentir demasiado de la dictadura mundana? ¿Puede la grey católica sentirse segura de seguir siendo "la sal de la tierra"?

Es de lamentar que por tratarse de cuestiones que atañen a la dimensión espiritual humana, para dirimir sobre las materias mencionadas, surgidas en ambos bandos bajo la influencia de corrientes filosóficas, no sea posible la utilización del método empírico, sustituido aquí por simples ob- 
servaciones psicológicas, freudianas, fenomenológicas y médicas. Importa también indicar que, en atención a la claridad con la que el santo obispo expuso sus ideas, para el presente trabajo se ha contado con los textos originales y solo con ellos, evitando otros muchos documentos de diversos autores con farrragosas elucubraciones sobre los mismos.

\section{JUVENTUD LICENCIOSA DE AGUSTÍN DE HIPONA}

Agustín de Hipona (354-430), más conocido como san Agustín, nació en Tagaste, de padre pagano, llamado Patricio, y madre cristiana fervorosa, llamada Mónica, en una ciudad situada en el norte de África, incluida en la actual Argelia, que formaba parte del Imperio Romano, en un tiempo límite entre la Edad Antigua y Media. Vivió en una época, 41 años después del Edicto de Constantino (Edicto de Milán), promulgado en el 313, por el cual el cristianismo pasó a ser una religión lícita. Época de gran ebullición de doctrinas filosóficas y religiosas, y cuando los bárbaros amenazaban con invasiones, que pronto se producirían poniendo fin al gran Imperio.

En este estudio interesa recordar la juventud de Agustín como joven libertino, con amplia experiencia sexual apenas traspasada la pubertad, porque tantas experiencias y por tanto tiempo desplegadas, sin duda alguna, le proporcionaron un material vivo y personal, además de lo que pudo oír, le contaran o leyera, para elaborar los juicios sobre la intimidad conyugal, que tan amplia repercusión han tenido en la historia de la Iglesia. Agustín supo lo que es el acto sexual con una mujer y la esclavitud que conlleva. Aunque estuviera muy arrepentido por tantos años de pecado, no es riguroso achacarle a ese sentimiento de culpabilidad el examen que llevó a cabo sobre la sexualidad matrimonial.

Es bien conocida la fuerte inclinación que tuvo al placer venéreo desde su adolescencia hasta bien pasados los treinta años y quizás resulte llamativa su pronta paternidad con tan solo dieciocho o diecinueve años. Pero no se piense que por satisfacer tales impulsos libidinosos abandonó los estudios ni desatendió sus inquietudes intelectuales y profesionales, filosóficas y literarias, en las que se implicó con calor. Ciertamente, durante su juventud se dejó llevar por la pasión de la carne, de lo que hay certeza gracias a lo relatado por él mismo en su libro "Confesiones". Una vez que 
por voluntad decidida de su padre, marchó a estudiar a Cartago, allí alternó con malas compañías y es posible que mantuviera contactos homosexuales, aunque nada hay confirmado al respecto:

He aquí con qué compañeros iba yo paseando las calles y plazas de Babilonia: me revolcaba en su cieno como si fuese en ungüentos olorosos, y para que me enlodase más y estuviese más tenazmente pegado a su inmundicia, el enemigo invisible me hollaba con sus pies en medio de ella, y me detenía allí engañado, porque era yo muy fácil de engañar en esto ${ }^{1}$.

Con 17 años se unió a una concubina cartaginesa, de quien se desconoce su nombre, y un año después tuvo un hijo de ella, Adeodato (Regalo de Dios). A ella amó y guardó fidelidad. Pasó años estudiando gramática y retórica y también literatura griega y romana. De regreso a Tagaste, enseñó gramática. Luego, vuelto a Cartago, enseñó retórica y otras disciplinas. Fue diligente proselitista maniqueo. Llegó a Roma para abrir una escuela, pero al año siguiente marchó a Milán. En esta ciudad se presentó a concurso de oposición y ganó la Cátedra Imperial de Retórica, año 384. En esta ciudad escuchó los sermones de San Ambrosio que le acercaron a la fe de Cristo.

Mónica, la madre de Agustín, instó a su hijo a que se casase, por bien de su carrera profesional, pero no podía hacerlo con la concubina que durante 14 años había compartido el lecho, pues la diferencia social entre ambos representaba un impedimento legal insalvable. Ante esta situación, Agustín optó por despedirla con el beneplácito de la madre que se afanó en buscarle esposa. La concubina marchó de su lado haciendo votos de no unirse a ningún hombre en toda su vida y dejó a su hijo al cuidado de Agustín y su madre. La ruptura fue muy dolorosa para el joven Agustín que por otras vías seguía satisfaciendo sus pulsiones sexuales, incapaz de vivir sin una mujer. En el intermedio antes de contraer matrimonio con una joven que su madre le buscó, pero que aún le faltaban dos años para alcanzar la edad núbil, se buscó otra concubina. En sus "Confesiones" reconocería tiempo después que no estaba suficientemente inclinado al matrimonio y por otra parte se sentía esclavo de la pasión sexual, "la enfermedad de su alma”.

${ }^{1}$ Agustín, San, Confesiones (=Colección Austral. N 1199). Espasa-Calpe, Madrid. 1973. (III, 8), p. 46. 
Agustín, se convirtió al cristianismo en el año 386, con 32 años, y en el otoño de ese mismo año renunció a la Cátedra de Retórica en Milan. Se retiró a una finca de su amigo Verecundo, situada en Casiciaco ${ }^{2}$, para prepararse a recibir el bautismo, tan anhelado por su madre y fue bautizado por San Ambrosio, en la Vigilia Pascual del año 387, juntamente con su hijo Adeodato y su amigo Alipo. En sus "Confesiones" reconoció que tan solo con la ayuda de la gracia de Dios fue capaz de mantenerse continente:

Juzgaba que sería sumamente infeliz y desdichado si me privaba de la mujer; y no pensaba en la medicina preparada por vuestra misericordia para curar esta misma dolencia, porque no la había experimentado, y porque creía que la continencia se había de alcanzar con nuestras propias fuerzas naturales ${ }^{3}$.

Agustín regresó a Tagaste en el año 388. En esta ciudad, fallecida ya su madre y su hijo, vendió todos sus bienes y el producto de la venta lo repartió entre los pobres. A partir de aquí surge una nueva historia.

\section{CRITERIO DEL SANTO OBISPO SOBRE LA SEXUALIDAD MATRIMONIAL: EN EL ACTO MATRIMONIAL HAY UN MAL}

S. Agustín a partir de los diecinueve años y tras la lectura de la obra "Hortensio", de Cicerón (106-43 a. C), se interesó por la filosofía:

Desde que en el año decimonono de mi edad leí en la escuela de retórica el libro de Cicerón llamado Hortensio, inflamose mi alma con tanto ardor y deseo de la filosofía, que inmediatamente pensé en dedicarme a ella. ${ }^{4}$

Estudió los distintos sistemas filosóficos griegos y mostró un especial interés por Platón (427-347 a. C.), bajo la óptica del neoplatonismo, siendo Plotino (205 d.C-270) y su discípulo Porfirio (233 d. C., 305), sus principales exponentes. También estudió el estoicismo, del que aceptó numerosas tesis.

${ }^{2}$ López Amat, A., El seguimiento radical de Cristo. I. Esbozo histórico de la vida consagrada, Ed. Encuentro. Madrid. 1987, p 65.

${ }^{3}$ Agustín San, Confesiones. Cit. p. 123.

${ }^{4}$ Agustín San, De la vida feliz. Cap I, 4. 
Hay base suficiente para pensar que sus juicios se matizaron de estas corrientes filosóficas, pero no por eso se pueden desestimar.

En los libros "De bono coniugali" (alrededor del 401), y "De nuptiis et concupiscentia" (418/19), están expuestas las principales ideas sobre la sexualidad matrimonial del obispo de Hipona, cuya repercusión en el mundo cristiano ha sido amplísima durante dieciséis siglos, erigidas como fundamento en los tratados morales. El concepto básico es que en el acto matrimonial está presente el mal de la concupiscencia o placer sexual. De esta idea se derivan otras más que igualmente han sido objeto de múltiples estudios y reflexiones. Por orden de importancia se traza la siguiente relación:

a) En el acto matrimonial está presente el mal de la concupiscencia o placer sexual.

b) Todo acto sexual conyugal fuera de la finalidad procreativa es pecado venial.

c) El matrimonio es un bien porque permite la procreación.

d) Hay condena para las prácticas anticonceptivas y el aborto.

e) Es superior la vida continente a la vida en matrimonio.

Hoy, aparte la cuestión del mal del acto sexual surge un segundo capítulo de crítica sobre el obispo de Hipona: el no haber sabido contemplar el acto sexual como "expresión de amor" entre los esposos, ni el "efecto unitivo" descrito en dicho acto, por el que cumple una segunda finalidad, además de la procreativa que le hace doblemente valioso.

En cuanto a lo malo del placer concupiscente o sexual interesa retener las ideas básicas de la doctrina del obispo de Hipona expuestas con claridad en varios textos, de los que se muestran los extractos siguientes:

IV. 5. Así, pues, la unión del hombre y la mujer, causa de la generación, constituye el bien natural del matrimonio. Pero usa mal de este bien quien usa de él como las bestias, de modo que su intención se encuentra en la voluntad de la pasión y no en la voluntad de la procreación. ${ }^{5}$

VI. 7. Pero ¿cómo es que cuando tenemos el cuerpo libre y sano de impedimentos, se tiene poder para mover y realizar las funciones propias

${ }^{5}$ Agustín SAn, El matrimonio y la concupiscencia (Libro Primero, IV. 5). Consultado: 31-3-2020. Disponible en:

https://www.augustinus.it/spagnolo/nozze_concupiscenza/index2.htm 
de los ojos, labios, lengua, manos, pies, espalda, cuello y caderas, y, sin embargo, cuando se trata de engendrar hijos, los miembros creados para esta función no se someten a la inclinación de la voluntad? Por el contrario, se espera que los mueva esta pasión, en cierto modo autónoma; aunque a veces no lo haga, teniendo el espíritu predispuesto, y otras lo realice, sin que el espíritu lo desee. ${ }^{6}$

VII. 8. Lo que hicieron después por la procreación es el bien del matrimonio, pero lo que antes cubrieron por vergüenza es el mal de la concupiscencia, que evita por todas partes la mirada y busca con pudor el secreto. En consecuencia, el matrimonio se puede gloriar de conseguir un bien de este mal, pero se ha de sonrojar porque no puede realizarlo sin él. Por ejemplo, si alguien con un pie en malas condiciones alcanza un bien aunque sea cojeando, ni es mala la conquista por el mal de la cojera ni buena la cojera por el bien de la conquista. Igualmente, por el mal de la libido no debemos condenar el matrimonio, ni por el bien del matrimonio alabar la libido. ${ }^{7}$

En términos teológicos el obispo de Hipona se preguntaba: ¿Cómo Dios, infinita bondad y sabiduría, podía ser el responsable de esas tendencias de orden inferior imprescindibles para la procreación? Sus respuestas fueron aceptadas durante dieciséis siglos y asumidas por la Iglesia Católica hasta mediados del s. XX: los apetitos desordenados hacia los placeres de cualquier tipo son consecuencia de una degradación moral que sobrevino sobre la naturaleza humana a raíz del pecado original, de Adán y Eva:

V. 6. Siendo las cosas así, evidentemente yerran los que piensan que se condena el matrimonio cuando se reprueba la pasión carnal, como si este mal viniera del matrimonio y no del pecado. ¿Acaso no dijo Dios a los primeros cónyuges, cuyo matrimonio bendijo, creced y multiplicaos? Estaban desnudos y no se avergonzaban. ¿Por qué, pues, después del pecado nace de aquellos miembros la confusión sino porque se produjo allí un movimiento deshonesto, que, sin duda, no lo padecería el matrimonio de no haber pecado el hombre? ${ }^{8}$

S. Agustín hubo de enfrentarse con ideas erróneas procedentes de los maniqueos y pelagianos, que contaminaban el pensamiento del pueblo

\footnotetext{
${ }^{6}$ Ibid. VI. 7.

7 Ibid. VII. 8.

8 Ibid. V. 6.
} 
llano, sacerdotes y obispos católicos. Para refutarlas tuvo necesidad de escribir cartas y libros en los que se mostró claro y rotundo. Se agradecen estos escritos porque sirven para confirmar la claridad de su doctrina. Como bien afirma Cormac Burke ${ }^{9}$, lo que más interesa, en su polémica con los pelagianos, es la naturaleza de la concupiscencia y así refiere que los pelagianos sostuvieron que esta es un bien natural (Contra Jul. Pel. IV, c. 21 (PL 45, 1348) $)^{10}$, y que solo son malos sus excesos (De nupt. et conc. II, c. 19, n. 34 (PL 44, 456) ) ${ }^{11}$. San Agustín mantuvo que es en sí misma una enfermedad o desorden. Contra Julián de Eclanum, que defendía muchas de las propuestas de Pelagio, escribió un tratado, en seis libros, sobre los contenidos que había que defender; en el relativo al matrimonio y a la sexualidad afirmó que la Iglesia católica estaba en el punto medio entre los maniqueos y los pelagianos:

Ella enseña (la iglesia) que la naturaleza humana es buena, como que es obra del Criador; pero que corrompida con el pecado original, necesita purificarse y curarse con la gracia del Redentor; que el matrimonio es bueno e instituido por Dios; pero que la concupiscencia es un desorden que no se deriva de aquella institución y que si ha sobrevenido en él es por consecuencia del pecado. ${ }^{12}$

Las ideas del obispo de Hipona chocan con la mentalidad de nuestro tiempo, tan dada al hedonismo y distanciada de Dios y precisamente por eso justifican una indagación, pero, estaban en consonancia con las epístolas de san Pablo, hoy en día incómodo por algunos de sus textos, que dejó escrito: "Pues la voluntad de Dios es vuestra santificación; que os apartéis de fornicación; que cada uno de vosotros sepa tener su propia esposa en santidad y honor; no en pasión de concupiscencia, como los gentiles que no conocen a Dios" (1 Tes. 4,3-5. RVR 1960).

La pasión fue valorada por el obispo de Hipona muy negativamente en tanto viene a ser una función que escapa a la propia voluntad del indi-

${ }^{9}$ Burke, C., San Agustin y la Sexualidad Conyugal. Consultado el 30 de Ju, 20. Disponible en: Augustinus 35 (1990), 279-297.

${ }^{10}$ Ibid.

${ }^{11}$ Ibid.

${ }_{12}$ Mr. Recevorr, Historia de la Iglesia. Tomo IV. Desde su fundación hasta el pontificado de N. SS. P. Gregorio XVI. Libro 10. Imprenta José Felix Palacios. Madrid 1842. P 301. 
viduo, contrapuesta a la razón que nos hace libres cuando impone su dictado a nuestra voluntad. El acto conyugal que se realiza a impulsos de la pasión encuentra aquí su mal, cuando el cuerpo se excita sin el consentimiento de la voluntad, algo realmente indecoroso y vergonzoso, que obliga a una realización oculta a los ojos de los demás. Sera necesario aclarar, como hace Cormac Burke ${ }^{13}$, que no hay nada de maniqueo en la actitud de san Agustín hacia el cuerpo, aunque admite que "nuestro cuerpo grava sobre el alma", de forma similar a san Pablo, que anhelaba la "liberación", pues se refería a una liberación de nuestra existencia material y terrena, hacia una existencia de comunión con Cristo.

\section{SOBRE LA PRESUNTA MALICIA DEL PLACER SEXUAL}

\section{El placer sexual (concupiscencia carnal) a debate}

El pensamiento de san Agustín no se crea que surge en un momento dado y desaparece al poco tiempo. La idea del dominio de la razón sobre la pasión ya está presente en Sócrates (470 a. C. - 399 a. C.), que la enseñaba en las calles, y en otros sitios públicos. Los seguidores del gran filósofo mantuvieron posiciones similares y entre las virtudes principales prudencia, justicia y fortaleza, establecieron la templanza como virtud a cultivar usando la mesura, sobriedad y continencia, de todo aquello que provoca placer. Estas virtudes que el cristianismo hizo suyas con el nombre de "virtudes cardinales", siguen vigentes en la actualidad revestidas con una gracia especial que procede del Espíritu Santo.

Hay, decía san Agustín, una ley impresa por Dios en el corazón del hombre, es la Ley Natural. Esta ley habla para quien quiere escucharla en forma de reproches y culpa, que no obedecen a influencias externas ambientales y educaciones, sino que es algo más profundo inserto en el alma humana. Así, por ejemplo, la joven sin escrúpulos que en una noche de diversión se abandona al placer sexual, con el primero que se le acerca se siente posteriormente como un klínex que se usa y se tira.

Desde el siglo XIX la Psiquiatría y la Psicología han querido ser disciplinas científicas y llegar al conocimiento de verdades aceptadas por

${ }^{13}$ Burke, C., San Agustin y la Sexualidad Conyugal. Cit. 
todos e irrebatibles mediante el método empírico u objetivo que estudia los datos de la realidad sensible, medibles y cuantificables. Atenerse a otros criterios subjetivos de opinión, de filosofías o creencias nos arrastra a la confusión, afirman los científicos, que desprecian las verdades reveladas, las conclusiones de la lógica metafísica o alcanzadas por otros medios. El problema es que el hombre, complejo psico-físico-espiritual, precisa de conocimientos que van más allá de la realidad sensible y por ello no pueden ser aceptadas como supersticiosas todas las verdades que escapan del empirismo.

\section{A. Deleite por atracción erótica}

El placer propio de la sexualidad se presenta como uno de los pilares básicos sobre el que se sustenta la ética sexual; durante veinte siglos rechazado como indecente, opuesto a la dignidad humana y desde hace décadas rescatado de su hoyo para ser encumbrado como bueno y saludable. Cuestionar la bondad o maldad del placer sexual exige en primer lugar precisar lo mejor posible el concepto: ¿Qué se entiende por placer sexual? No es lo mismo la complacencia que un hombre puede sentir ante la belleza sexuada de una mujer "de bandera", a la admiración y aceptación que otra mujer puede experimentar ante idéntica contemplación. En términos generales, el hombre experimenta complacencia ante la presencia de la mujer como ser sexuado, especialmente ante ciertas mujeres. Hay un componente sexuado que provoca placer, que es placer sexual, del hombre hacia la mujer y viceversa. Es un placer muy específico, que se experimenta con la simple contemplación, sea ante un ser real o imaginado.

Con base en observaciones fenomenológicas en los últimos años se han descrito tres tipos principales de placeres sexuales expuestos por Mora en el $2010{ }^{14} \mathrm{y}$ en $2017 .{ }^{15}$ Un primer y elemental placer fue denominado "deleite por atracción". Se trata de un sentimiento único, sin parangón con ningún otro, de entrada, preferentemente pasivo y contemplativo, que se experimenta con carácter muy selectivo, generalmente ante personas de sexo contrario. El componente sexuado es muy marcado e indispensable para que una persona "guste", por encima de otros valores reconocidos. Por eso, es frecuente oír alabar a alguien en términos de "es

\footnotetext{
${ }^{14}$ Mora, José. Ma., Te quiero. Ed. Ulzama. Pamplona.2010. pp. 108-129.

${ }^{15}$ MorA, JosÉ. Ma., Tálamo conyugal. Ed. Ulzama. Pamplona. 2017. pp. 105-130.
} 
muy femenina", "acogedora", "dulce", "tierna", "muy sentida", o bien, "es muy varonil, "muy independiente", "trabajador incansable", "resolutivo", "íntegro", "un hombre cabal".

En múltiples ocasiones el "deleite por atracción erótica" se manifiesta como único fenómeno de sexualidad limitado a sí mismo. En la vida social, amistades, vecinos, compañeros de trabajo, personas conocidas por múltiples causas, con las que hay un trato frecuente son objeto de atracción sexual. Son personas que "gustan", aunque por imperativo social muchas veces se oculte esta atracción. Actores, actrices, famosos del cine o de la televisión, "gustan" y con frecuencia apetece ver una película o serie a su reclamo. Charlas que se hacen interminables por el encuentro ocasional de dos personas que se "gustan". Parejas que inician una relación amorosa y se complacen uniendo sus manos y rostros.

La intensidad del deleite es muy variable, habitualmente moderado, no llega a entontecer a quien lo experimenta, pero en ocasiones es tan intenso que viene a ser como una especie de deslumbramiento cegador del que surge el enamoramiento por "flechazo" y la persona afectada queda cautivada por los encantos de otra. En estos casos, tal fascinación se acompaña de una sobreposición de otros elementos, productos mentales del sujeto, que desorbitan la simple atracción erótica, piénsese en el fenómeno de la "cristalización", descrito por Stendhal en el siglo XIX.

\section{Diferencias entre el "deleite por atracción" y el "deseo"}

El "deleite" es distinto al "deseo" de copular, entre otras cosas, como la admiración estética, el reconocimiento de bellas cualidades personales, la necesidad de cariño, el mero simpatizar. El "deleite" surge de la simple contemplación, real o imaginada. Es fundamentalmente pasivo, pero no del todo, porque quien lo experimenta intuye que alcanzar su plenitud supondría el acercamiento físico personal y la fusión con ese tú que anula el sentimiento íntimo de soledad e incompletud.

Interesa especialmente diferenciar el "deleite de atracción" del "deseo carnal". Fue la psiquiatra Helen Singer Kaplan (1929-1995) ${ }^{16}$ quien incluyó el "deseo", como elemento necesario para que la cópula entre el

${ }^{16}$ KAPLAN, Hele. Manual ilustrado de terapia sexual (= Claver. 026220). Ed. DeBolsillo 2010. 
hombre y la mujer pudiera realizarse. Ella estableció el llamado "modelo trifásico" como esquema básico en toda realización sexual humana, aceptado por la sexología a nivel internacional, y que vino a remplazar el modelo de los cuatro factores establecido a mediados del pasado siglo por Masters y Johnson (Excitación, altiplano, orgasmo y resolución) $)^{17}$. El modelo "trifasico" incluye el "deseo" junto a la "excitación" y "orgasmo" en todo acto sexual consumado. Tres fases a tener en cuenta para tratar las "disfunciones sexuales", que, según Kaplan, tienen su origen en una de las tres. El "deseo", como aportación de esta doctora, es el especial estado de ánimo, no pasivo, sino ardoroso, que incita a la actividad sexual, para satisfacer lo que se presenta como primordial necesidad de forma un tanto indiscriminada. Las diferencias entre "deseo" y "deleite por atracción" son notorias:

a) El "deleite por atracción" es extremadamente selectivo en sus preferencias personales, mientras que el deseo no distingue en sus elecciones.

b) El deseo mantiene una estrecha relación con el cuerpo y la estructura endocrino-neurofisiológica, razón por la cual la apetencia por la actividad libidinosa está muy influida por el movimiento hormonal, estados de estrés o de cansancio, edad, enfermedades, etc. No ocurre esto con el "deleite por atracción erótica", que una vez alcanzada la pubertad se mantiene constante, incluso en edades muy avanzadas de la vida y salva todo tipo de eventualidades existenciales.

c) Si se atiende a los "estratos de la personalidad" que desde Nicolay Hartmann ${ }^{18}$ (1882-1950) se han venido estableciendo hasta nuestros días, se puede afirmar que el "deseo" surge de un estrato somatopsíquico o vital, compartido con los animales, mientras que el "deleite por atracción erótica" pertenece a un estrato superior específico de la especie humana, de la noopsique en concreto, si nos atenemos al esquema de Pophal ${ }^{19}$ o de Thiele R. ${ }^{20}$

${ }^{17}$ Masters William H. y Johnson Virginia E. Respuesta Sexual Humana. Intermédica. Buenos Aires.1 (Argentina).1976, p. 3-7.

${ }^{18}$ LERSCH, PHILIPP, La estructura de la personalidad. Ed. Scientia. Barcelona 4. 1966. p. 78.

${ }^{19}$ Esta teoría se ilustra con una pirámide o triángulo isósceles en cuya base se halla el "terreno" y lo "instintivo", a lo que se añade una gruesa capa del estrato del "sentimiento" y, finalmente, culmina con la esfera (punta o aguja superior) del "espíritu".

${ }^{20}$ LersCh, PhILIPP, Cit. p. 79 
Por todo ello, queda claro que el "deleite" o "gustar" sexual es diferente de las siguientes emociones:

- No es un "deseo" de placer voluptuoso-genital.

- No es admiración hacia alguien, sea por su belleza, estilo, educación, ni por otras excelentes cualidades morales o intelectuales.

- No es un sentimiento de agrado o simpatía.

- No es sentimiento de cariño.

- Ni por una mezcolanza de los anteriores enunciados.

\section{La importancia del "deleite por atracción” en el acto conyugal}

Si bien el "deleite por atracción erótica" no incita al acto sexual es importante señalar que tampoco está reñido con él. Es más, el coito puede resultar desagradable, y hasta asqueroso si falta el "deleite por atracción", pero cuando está presente la experiencia es agradable, tanto más agradable cuanto más acusada es la atracción, por lo que no es raro escuchar de unos enamorados que "todo resultó muy bonito". La presencia del "deleite por atracción" no se limita al comienzo de la secuencia del ciclo trifásico, porque persiste a lo largo de la excitación sexual hasta el orgasmo, y la fase de resolución post-coito se desenvuelve entonces con una tranquila placidez.

El factor "gustar" no ha sido acertadamente valorado en Psicología, quizás por haberse constituido en elemento determinante y exclusivo de la literatura romántica y por tal causa excluido de toda investigación sexológica. Así, por ejemplo, el matrimonio investigador Masters (19152001) y Johnson (1925-2003), después de realizar en laboratorio estudios sexológicos con metodología científica omitieron cualquier referencia al "gustar" sexual, por no percatarse de su existencia o no concederle ningún interés. Cuando años después Helen Singer Kaplan (1929-1995) modificó el esquema del citado matrimonio y estableció el modelo trifásico de respuesta sexual (deseo, excitación y orgasmo), también omitió el "gustar", diferente al "deseo" con el que podría confundirse, pero este apunta principalmente a la excitación y al orgasmo y el "gustar" no.

La importancia del componente "gustar" radica en la necesidad de su presencia en todo el acto sexual desde su inicio hasta la resolución orgásmica para que las distintas fases de dicho proceso sean satisfactorias. Quiere ello decir que el "gustar" puede faltar en una cópula determinada sin que esta se bloquee, y así continúa su desarrollo hasta la consumación, 
pero eso nunca se produce sin un grave deterioro de esa cópula, que difícilmente se repetirá ante una experiencia que resultó desagradable, con frecuencia calificada como repulsiva.

La clínica demuestra la existencia de "frigideces facultativas". Mujeres que son frígidas ante determinados hombres y no para otros y casos diferente de mujeres con "frigidez obligada" que presentan esta perturbación para todos los hombres. Estos últimos casos se han venido considerando producto de neurosis y conflictos psíquicos, pero hay que asentar la hipótesis de que todo sea mucho más sencillo y obedezca a una carencia del factor "gustar" de carácter constitucional que hace odiosa la relación heterosexual. El estudio del factor "gustar" puede ser igualmente de interés en aquellas personas que a sí mismas se consideran "asexuales", y afirman no sentir atracción por ningún sexo.

\section{B. "Placer voluptuoso"}

Siguiendo el esquema de Kaplan, toda experiencia sexual humana se inicia por el "deseo". La fase siguiente es la "excitación sexual". Son momentos en los que los genitales, del hombre y de la mujer se preparan anatómica y fisiológicamente para la penetración y tras ella la excitación se mantiene hasta el orgasmo. Es una fase de placer muy específico, porque carece de plenitud en sí misma. Freud afirmaba que a esta fase se llegaba por tres clases de estímulos: los procedentes del mundo exterior, los procedentes del interior orgánico corporal y los originados por la vida psíquica. Pues bien, una vez alcanzada la excitación, Freud reconocía en ella un estado de tensión que como tal debía ser desagradable, y no lo era, sino placentero. ¿Cómo podía ocurrir tal cosa? La respuesta le obligó a un análisis detenido del fenómeno: observó que hay realmente un "placer inicial", pero es un placer que invita a un placer mayor, a conseguir con una mayor profusión de estímulos, y por esa tensión que se crea se alcanza un placer más intenso, que a su vez exige un placer mayor aún, hasta llegar al "placer final" que cursa con expulsión de materia orgánica (semen y mucosidades) por los genitales. ${ }^{21}$

${ }^{21}$ Freud, Sigmund, Obras completas. Una teoría sexual. II. Ed. Biblioteca Nueva. Madrid. 1967. p. 806. 
Al placer que se inicia con los estímulos pertinentes, diferente al "deleite por atracción", y que termina en el orgasmo ha sido llamado "placer voluptuoso". Freud reconocía en él un carácter apremiante y ascendente en intensidad hasta el orgasmo. Pero el creador del psicoanálisis no advirtió que el placer sexual originado por peculiares estímulos iba acompañado de "deleite de atracción," que igualmente se incrementa conforme se invade la intimidad del ser que atrae y gusta. Se podría decir que dos caballos de distinta raza tiran de un mismo carro hasta alcanzar la meta. Una meta con distinta significación para los cuadrúpedos, pues uno corre en pos del placer por el placer, que al alcanzar cierta intensidad pide su liquidación, y el otro aspira a la unión total con quien nos completa y nos hace sentir en plenitud.

\section{El "Placer voluptuoso en la infancia"}

De la existencia del "placer voluptuoso" completamente distinto al "deleite por atracción" hay sobradas evidencias, gracias sobre todo a que se manifiesta en edades anteriores a la pubertad, cuando la atracción de los sexos aún no se ha manifestado y a causa de la inmadurez biológica la reacción genital puede ser nula, escasa o incompleta. Algunos autores como Kinsey han afirmado que bebés de seis meses solían masturbarse, pero las manipulaciones genitales del bebé, en ambos sexos, se prestan a conjeturas en cuanto a su significado exploratorio o placentero, ya que los lactantes no cuentan sus sentimientos, en opinión atinada de Offer y Simón (1982), y por lo mismo resultan temerarias tales afirmaciones.

A partir de los 18 meses, con el desarrollo del lenguaje y hasta los cinco años, el niño pasa por una etapa de exhibicionismo fálico y los psicólogos descubren en estas manifestaciones el placer de manipular su pene. Pero el término placer aquí empleado es impropio y sería mucho más acorde con la realidad hablar de regusto, gustillo o manipulación de los genitales como distracción.

El placer voluptuoso auténtico en la infancia se manifiesta en forma de un estado emocional singular, un placer o "regusto lascivo", que se "disfruta" en soledad o en compañía de otros con los que se comparte y huye de la presencia de personas mayores, porque avergüenza. A veces este placer sonrojante tiene una repercusión fisiológica focalizada en los genitales, especialmente en niños varones. Las experiencias que lo provocan son variadísimas, conocidas desde las primeras descripciones sexológicas del XIX. 
Ya a partir de los 5 años, o incluso antes, y sobre todo de los 7 a los 10 años hay manifestaciones claras de placer voluptuoso, grabadas con fuerza en la memoria, a veces como el recuerdo más antiguo de la vida, y son referidos en encuestas y estudios psicobiográficos. Hay niños que experimentan movimiento en los genitales externos (erecciones, congestión...) acompañando a las emociones lúbricas desencadenadas por elementos exógenos. Es clásico, por su frecuencia, el juego erótico a ser médico y pedir a la niña, en su papel de enferma, bajarse las bragas para luego juntar su genital al de ella, intentar la penetración y proceder a manipulaciones diversas, en las que no se produce todavía una auténtica excitación, pero sí un claro regusto al hacerlo. Estos manoseos, exhibiciones y demás maniobras los realizan niños de una edad similar, que encuentran el lugar y el momento adecuado en razón a la amistad o familiaridad (entre hermanos, o más frecuentemente entre primos). Hay fantasías de ser dañado o dañada, añadidas al hecho de despojarse de las ropitas interiores.

Encontrar revistas en las que se encuentran fotografías de personas mayores desnudas constituye descubrimientos que se guardan celosamente para satisfacción propia, o enseñarlas a otros niños con igual finalidad. Fotografías o reproducciones litográficas de pinturas y esculturas de desnudos, admirados por adultos como obras de arte, en niños en edad prepuberal pueden servir de estímulos de placer voluptuoso. Utilizar ropa interior del otro sexo y dar rienda suelta a imaginaciones lascivas también ocurre. La simple fricción de los genitales con enrojecimiento facial; la introducción del dedo en el ano y otras manipulaciones con el propio cuerpo, o con el de otro u otra, no es nada excepcional.

En estos últimos años los contenidos pornográficos que con facilidad se pueden encontrar en Internet provocan en los niños una imagen distorsionada de la sexualidad, basada exclusivamente en la genitalidad. Son los niños que han merecido en el Reino Unido la denominación de niños de la generación XXX, o niños de la generación porno (activos genitalmente pero con la inmadurez propia de la edad), que según ciertas estimaciones, en España, se extiende a más de la mitad de los adolescentes varones. En la mujer no ocurren las cosas exactamente igual, pero en los últimos años las diferencias se han reducido notablemente.

La pura voluptuosidad y la reacción genital acompañante es una realidad que surge ya en la niñez ante muchas circunstancias. A veces, la in- 
tensidad de la excitación es tan fuerte que no se olvida, y el niño puede voluntariamente repetirla para experimentar placer. De esta forma se fijan conductas, conocidas en medicina como parafílicas, (fetichismo, sadismo, masoquismo, zoofilia, exhibicionismo, voyerismo, etc.) que persisten en la edad adulta e imposibilitan, o alteran gravemente, el comportamiento sexual normal.

La represión voluntaria del placer voluptuoso es una alternativa aceptada por niños y jóvenes bajo la influencia de una adecuada educación sexual. Esta represión nada tiene que ver con la conocida represión neurótica descrita por Freud, por la que una persona mantiene en su inconsciente contenidos sexuales desagradables o desaprobados que posteriormente se manifiestan transformados en síntomas neuróticos. La represión consciente, o dominio voluntario del placer excitante de la genitalidad se produce en todo aquel, hombre o mujer, que, por los motivos que sea, rechaza estos placeres que juzga de inferior categoría, de naturaleza fisio-biológica, que nos aproximan a la animalidad. El que rechaza este placer no es que no lo experimente, sino que evita su progresión y todos aquellos estímulos sensoriales o ideativos capaces de provocarlo.

\section{El problema de los estímulos que incitan al "placer voluptuoso".}

Dicho está que el "placer voluptuoso" que igualmente se puede denominar "lascivo", "lujurioso" o "lúbrico", surge a través de unos estímulos de distinta procedencia. En primer lugar, se encuentran los que llegan del mundo exterior a través de los órganos de los sentidos. En la actividad vital cotidiana de cualquier ser humano hacen acto de presencia estos estímulos, bien sea porque se han buscado expresamente o bien, han surgido de forma inesperada. Muchos de ellos están producidos por empresas de comunicación audio-visuales (prensa, cine, radio, televisión, internet). Se trata en gran parte de estímulos indefinidos, lo que quiere decir que pueden estimular a unas personas y a otras no y se les conoce como "estímulos eróticos". Tan solo cuando son producidos con la única finalidad de excitar la libido, se mencionan como "pornográficos", con un potencial excitador generalizado, para todo el mundo. Hay estímulos psíquicos en forma de recuerdos, imaginaciones y fantasías, de contenidos muy variados, pero bajo el común denominador de detenerse en el aspecto más soez y obsceno de las relaciones humanas. También son frecuentes los pensamientos sádicos y masoquistas. En tercer lugar se encuentran las estimulaciones 
corporales, incluidas las zonas erógenas, que pueden ser producidas por uno mismo (autoeróticas) siendo la masturbación la más común de todas, o provocadas por otra persona.

El hecho cierto es que estos estímulos, en cualquiera de sus variedades, agota su potenciar excitador con el uso frecuente, lo que obliga a cambiar el estímulo por otro novedoso, o bien, si se mantiene el mismo estímulo, a intensificarlo hasta alcanzar el efecto deseado. El ginecólogo holandés Van de Velde, a principios del XX, quiso que las esposas disfrutaran del placer sexual conyugal, que según pudo comprobar en su consulta hablando con múltiples matrimonios, no compartían con los maridos. Ello les creaba insatisfacción y desgana a la hora de un nuevo acto conyugal. Van de Velde en su libro "Matrimonio ideal", que tuvo amplísima difusión por toda Europa, enseñó de qué forma el varón en el acto conyugal debía excitar a la esposa y en esta pedagogía incluía la necesidad de cambiar periódicamente los estímulos para que el resultado fuera el apetecido. Entre otras cosas mostró las diez posturas que una pareja podía adoptar en el coito: seis enfrentados los esposos y cuatro de espaldas la mujer.

A causa del mismo efecto, hay matrimonios que buscan las estimulaciones voluptuosas de forma extramarital. Infidelidades consentidas en algunos casos y hasta aconsejadas por sexólogos para dar cumplida satisfacción a estas necesidades sexuales. Son los llamados "matrimonios abiertos", en los que tanto el marido como la mujer permiten e incluso aconsejan a su pareja, en un ejercicio de excéntrica liberalidad, lleve a cabo cuantas relaciones sexuales desee con otras personas. En esta misma línea se encuentran los juegos de intercambio de pareja, el "menage a trois" y los "masajes" en casas especializadas. En Psicología se conoce con el nombre de "efecto Coolidge" la tendencia del marido a tener relaciones sexuales con otras mujeres, en recuerdo a la anécdota del presidente de EE UU Calvin Coolidge que visitaba una granja en compañía de su esposa y observó como el gallo copulaba con múltiples gallinas. En otras ocasiones, cuando la infidelidad supone un quebrantamiento del pacto de fidelidad establecido, la ruptura del matrimonio y de la familia es muy difícil de evitar.

El estímulo sexual-voluptuoso que se alimenta de lo nuevo permite comprender la "escalada" que puede experimentar una persona casada o no en busca de estímulos excitantes de la genitalidad, provocándole una 
"adicción al sexo". De tal forma, en un momento dado, agotados todos los estímulos usados en su propia pareja, puede ocurrir que acuda a relaciones extramatrimoniales y después a los más extravagantes, imaginativos o criminales actos en busca del placer lúbrico. Este trastorno, conocido desde tiempos inmemoriales en la mujer con el nombre de ninfomanía y en el hombre de satiriasis fue mencionado por el psicoanalista austriaco Otto Fenichel (1897-1946) hace unos 70 años. Empleó por primera vez el término "adicción sexual" para referirse a una sintomatología sexual que comparaba con la adicción a las drogas, que por entonces despuntaba. Años más tarde el norteamericano Patrick Carnes divulgó esta adicción en sus obras: "Out of the shadows, understanding sexual addictions" 22 y "Don't Call it Love: Recovery from Sexual Addiction," ${ }^{23}$ y logró que a partir de las últimas décadas del pasado siglo fuera más conocida y mejor diagnosticada. Esta adicción supone una dependencia o esclavitud que obliga a una actividad génito-orgásmica desaforada: masturbación compulsiva, abusos sexuales, múltiples relaciones promiscuas con parejas heterosexuales u homosexuales, encuentros con personas desconocidas, recurso continuo a la pornografía, prostitución o líneas telefónicas porno, exhibicionismo, pedofilia, turismo sexual, etc. Es una conducta claramente compulsiva; una tendencia irrefrenable y reiterativa, dirigida a una conducta sexual de la que queda una agobiante sensación de insatisfacción. Los sentimientos que provoca esta adicción son muy negativos, tan intensos a veces que conducen al suicidio: descontento, sentimiento de estar haciendo cosas indebidas, desprecio de sí mismo, autoestima por los suelos y desesperación.

\section{Claras diferencias entre el "placer voluptuoso" y el "deleite por atracción"}

Los estímulos que provocan el "deleite por atracción" son muy distintos a los anteriores y básicamente se reducen a la percepción por parte del hombre y de la mujer del cuerpo sexuado de la mujer y del hombre respectivamente. Cuerpos animados de un interior psíquico que dispone de unos rasgos de personalidad diferentes para cada sexo. De tal forma

${ }^{22}$ CARnes, PAtrick, J., Out of the shadows, understanding sexual addictions. CompCare Publishers, Minneapolis. 1983.

${ }^{23}$ Carnes, Patrick, J., Don't call it love: Recovery from sexual addiction. Bantam Books. New York. 1991. 
que al hombre le gusta el cuerpo de la mujer y también sus movimientos, porte, gestos, ademanes, expresiones verbales, timbre de voz, porque todo ello habla de una personalidad femenina que gusta, como gusta el cuerpo con el que forma una unidad psico-física-espiritual. Igual ocurre con la mujer respecto al hombre.

Los estímulos que provocan complacencia, "deleite", a diferencia de los voluptuosos no se acompañan de tensión alguna que exija una estimulación más intensa para un deleite mayor. No obstante, es evidente que la proximidad física lo incrementa. Por eso, la fotografía de una mujer gusta al hombre, pero si tal mujer se percibe en su realidad corpórea cerca de uno, entonces la complacencia es mayor, y aún será mayor si en un abrazo el hombre percibe lo mullido de su carne. Podrá todavía llegar a extasiarse con la suavidad de su piel, y la calidez de su voz si los sentidos del tacto y oído entran en juego. Quiere esto decir que el "deleite por atracción" se incrementa conforme el contacto físico de los cuerpos avanza hacia un punto final que no puede ser otro que la unión íntima y total. Será una unión que provoca un grato y sosegado placer que se fusiona y confunde con aquel otro de tipo voluptuoso preparado ya a poner fin a la gran tensión acumulada.

El apremio propio de la voluptuosidad impide con mucha frecuencia que los momentos previos al orgasmo se prolonguen y la pareja pueda recrearse disfrutando de una acopladura que debería no tener fin. La experiencia de clara ambivalencia que toda pareja tiene al final del coito de querer y no querer que todo termine es muy ilustrativa de los dos tipos de placeres que confluyen en el acto sexual.

El "placer voluptuoso" y el "deleite por atracción" coinciden en el curso de la cópula hasta el orgasmo, pero entre ellos hay claras diferencias:

El deleite, a diferencia de la excitación voluptuosa, no se impone sobre la voluntad de los esposos, ni aturde el entendimiento, tampoco es motivo de vergüenza por los actos que se realizan a causa de su disfrute.

El deleite de la atracción cursa sin apremio ni tensión alguna y en tal sentido es más placentero que el placer voluptuoso, al que acompaña, pero también se produce con independencia de él, como se dijo capítulos atrás. 


\section{C. "Placer orgásmico"}

Constituye el tercer tipo de placer que se contempla en todo acto sexual hombre-mujer consumado, aceptado como el punto álgido o clímax del placer sexual voluptuoso. En múltiples ocasiones se busca este placer con independencia de todo lo demás y para tal fin se utiliza el coito u otros medios físicos, especialmente la masturbación, acompañada a veces de imágenes o fantasías excitadoras. En la mayoría de los orgasmos hay emisión de sustancias orgánicas, en el hombre de semen, para que la función reproductora pueda producirse; en la mujer hay secreción lubrificante y expulsión del tapón cervical.

Muchos niños ya en edades próximas a los diez años se provocan este placer por frotamiento de los genitales usando la mano, el asiento u otros medios. Es práctica que sobreviene bien como un descubrimiento personal, bien porque lo han visto hacer en otros niños, bien porque lo han oído, o alguien se lo ha enseñado o aconsejado.

En los adultos masculinos en el orgasmo se produce la propulsión casi simultánea de sustancias biológicas. La eyaculación y el orgasmo son procesos diferentes, que suelen ocurrir de forma sincronizada. Pero, no siempre ocurre así, pues hay orgasmos sin eyaculación, o con eyaculación retrógrada, (semen que no sale al exterior porque fluye a la vejiga urinaria), y eyaculaciones no precedidas de orgasmos. De los pormenores anatomo-fisiológicos de la función sexual se sabe que están regulados por el sistema nervioso central y el periférico. Las estructuras cerebrales que más participación tienen son: el septum medio, la corteza límbica y el núcleo medio dorsal del tálamo. El sistema nervioso periférico participa con centros neurológicos ubicados en la médula sacra: S2, S3 y 54, y en la médula cervical: C3 a C6.

En la mujer ocurre de forma similar y destaca el hecho de la ausencia de orgasmos en muchos coitos y de la cada vez más frecuente práctica masturbatoria, a diferencia de épocas pasadas en la que era excepcional. La masturbación como medio de provocar el placer orgásmico lo ha descrito con toda frialdad la escritora y crítica de arte Catherine Millet en un libro que publicó en el 2001 ("La vida sexual de Catherine M".), en el que describe sus experiencias con hombres que hacían turno para disfrutar de su cuerpo, que ella libremente les ofrecía, para finalmente masturbarse con lo que experimentaba un placer físico mayor que todos los anteriores. 
Un hecho a destacar conocido por sexólogos, urólogos y andrólogos, es la posibilidad en algunos hombres de eyacular con fuerte erección pero sin experimentar orgasmo, de eyacular sin tener una erección completa, e incluso sin erección alguna. No constituyen la regla, por supuesto, pero, aunque en escaso porcentaje, estos casos se producen sobre todo en hombres que durante largo tiempo no han tenido emisiones de semen y manifiestan un umbral de excitación muy alto, en prácticas sexuales distintas a la penetración vaginal.

\section{Polución nocturna}

Este hecho conocido también como "sueño húmedo", es una eyaculación involuntaria de semen durante el sueño. Se considera un fenómeno normal, frecuente sobre todo en la adolescencia, aunque se presenta también más rara vez en edades posteriores y en casados. En ocasiones no se relaciona con ningún sueño y tan solo se descubre al despertar, otras veces se produce al final de un sueño erótico que cursa con orgasmo, y también se producen poluciones en sueños placenteros de tipo sexual, pero sin orgasmo.

A juicio de los urólogos, la eyaculación nocturna puede ser provocada por un mecanismo automático del organismo para mantener el buen funcionamiento de los genitales masculinos. Cuando no hay coito ni masturbación las vesículas seminales, donde se acumula el esperma, se llenan y originan una erección, la cual a su vez provoca una contracción en la próstata y esta a su vez motiva la expulsión del líquido. Estos especialistas añaden que la mayoría de las erecciones durante el sueño ocurren en las primeras horas de la mañana, cuando los niveles de testosterona (hormona sexual masculina) en la sangre son máximos, lo que facilita la polución.

\section{OPOSICIÓN DE CRITERIOS ECLESIALES SOBRE EL ACTO SEXUAL}

\section{Criterios de la Iglesia post-conciliar}

La declaración de Agustín de Hipona de existir un mal en el acto conyugal empezó a cuestionarse en el siglo XX, especialmente a raíz del Concilio Vaticano II (1962-1965). El criterio agustino se tachó de ser una "visión negativa" de la sexualidad humana y los papas postconciliares lo 
ignoraron, en un ambiente eclesial dominado por el modernismo que los primeros papas del siglo XX, Pío XI y Pío XII no consiguieron sofocar.

El papa Pío XI (1857-1939), cuyo pontificado ya entra en el siglo XX, mantuvo en su encíclica "Casti Connubii" $(1930)^{24}$ los criterios seculares sobre esta materia; se refirió al "débito conyugal" como obligación recíproca a cumplir, e igualmente como derecho a demandar entre los esposos, sin olvidar el amor que san Pablo recomendó en toda actividad esponsal. Abordó el espinoso problema de la anticoncepción que en su tiempo ya se presentaba como un problema sociológico, siendo muy contundente en sus afirmaciones: condena que los cónyuges tengan relaciones únicamente los días no fértiles para evitar la procreación.

El papa Pacelli, Pío XII (1876-1958), fue el último papa que sobre la actividad sexual en el matrimonio mantuvo los criterios tradicionales de la Iglesia. Sobre el acto matrimonial mantuvo una visión ya enunciada por san Agustín: no es pecaminoso ni censurable el placer en el acto matrimonial, pero las facultades inferiores de la naturaleza humana, tras la caída de Adán, incitan a veces al hombre a lo que no es honesto. Consideró el uso del matrimonio una "impureza legal," y rechazó, como grave error, la idea de que el matrimonio sacramento proporciona a la personalidad humana su natural desarrollo y debida perfección, y que por la gracia recibida une mucho más las almas a Dios, que por la simple guarda de la virginidad. Argumentaba que el sacramento del matrimonio es gracia de Dios para que los cónyuges se amen y salven los obstáculos que la vida les pueda presentar, pero no eleva las almas a Dios y por eso san Pablo recomendaba a los esposos guardar días de abstinencia sexual para dedicarlos a la oración. Afirmó que el uso del matrimonio impide que el alma se emplee totalmente en el servicio de Dios; llegó a la misma conclusión que otros autores de aceptar el estado virginal consagrado a Dios como forma de vida de mayor perfección que la vida matrimonial, santificada con el Sacramento. No hizo ninguna declaración dogmática, ni escribió en encíclica alguna que seguir el método Ogino-Knaus fuera aceptable moralmente para controlar la natalidad. Se opuso a toda especie de inseminación artificial, con un donante de semen extraño a la pareja, y aun entre esposos, puesto que esta práctica no se hallaba comprendida entre los derechos de los esposos y era contraria a la ley natural y a la moral católica.

${ }^{24}$ Pío XI. Carta encíclica Casti Connubii. Libreria Editrice Vaticana. 1930. 
Tras el Concilio surgen cambios importantes en la Iglesia que contradicen lo establecido durante siglos:

- No hubo alusión alguna a la obligación de los maridos de mantener con sus mujeres relaciones sexuales honorables, pues se aceptó sin más que en el matrimonio estas relaciones son honestas y honorables.

- La Iglesia postconciliar no concede más valor al estado virginal de los que consagran su vida a Dios que al de los casados. Considera por igual la santidad que se puede alcanzar en un estado o en otro.

- El acto sexual es considerado noble, honesto y digno. "Este amor-de los esposos- se expresa y perfecciona singularmente con la acción propia del matrimonio. Por ello los actos con los que los esposos se unen íntima y castamente entre sí son honestos y dignos" (Constitución Pastoral Gaudium et Spes GS, 49).

- En el acto sexual hay una donación mutua de los esposos. Es por tanto un acto de amor altruista: "Un tal amor, asociando a la vez lo humano y lo divino, lleva a los esposos a un don libre y mutuo de sí mismos" (GS, 49).

- Pablo VI sostiene en su encíclica "Humanae Vitae", que en el acto matrimonial tiene lugar "la conexión inseparable, establecida por Dios entre la significación unitiva y la significación procreativa, que son ambas inherentes al acto conyugal" (HV,12). Afirmación novedosa en el catolicismo.

- Juan Pablo II afirmó y enseñó en su libro "Amor y responsabilidad" 25 que el acto sexual es expresión del amor esponsal, y esta idea la reiteró en su encíclica "Familiares consortio" (FC, 11). Un concepto contrario a la doctrina tradicional que mantenía, desde el apóstol Pablo, que el acto matrimonial es expresión del apetito concupiscente.

- Juan Pablo II afirmó que en el coito los esposos dejan de sentir su soledad original ("Varón y mujer. Teología del cuerpo" (1996). Afirmación también novedosa en la doctrina católica. 
- En la Exhortación Apostólica Postsinodal del papa Francisco "Amoris Laetitia" (2016), claramente se niega la validez del criterio agustiniano. En el capítulo cuarto, titulado "El amor en el matrimonio" se puede leer:

152. Entonces, de ninguna manera podemos entender la dimensión erótica del amor como un mal permitido o como un peso a tolerar por el bien de la familia, sino como don de Dios que embellece el encuentro de los esposos. Siendo una pasión sublimada por un amor que admira la dignidad del otro, llega a ser una «plena y limpísima afirmación amorosa», que nos muestra de qué maravillas es capaz el corazón humano y así, por un momento, «se siente que la existencia humana ha sido un éxito».

\section{Argumentos a favor de san Agustín}

\section{a) La "sublimación" de la libido}

Tras el Concilio Vaticano II se quiso anular el aspecto nocivo intrínseco al acto conyugal, denunciado por Agustín de Hipona, pero no se dieron ningún tipo de razones para ese abordaje. Pues bien, después de dividir los distintos tipos de placeres que intervienen en dicho acto se evidencia, según se ha expuesto, que el "placer voluptuoso" y el "orgásmico" conllevan los caracteres negativos que el santo obispo denunció en su día, por lo que sería aconsejable como mínimo replantearse el tema.

Hay otras razones a favor de san Agustín, que se desprenden de la simple observación empírica. Fue el creador del Psicoanálisis Sigmund Freud quien primero las mencionó en su profusa producción literaria-científica. Afirmaba que para el avance cultural era preciso un cierto grado de represión de los impulsos sexuales. Años antes, en su teoría sobre la vida sexual, había establecido que cuando una persona es capaz de dominar los impulsos de su libido, y entendía por libido "la fuerza en que se manifiesta el instinto sexual", entonces esa fuerza se "sublima": es decir, la libido viene a consumirse en actividades culturales sean, literarias, artísticas, científicas, cívicas o similares. Decía Freud:

Una vez que la tendencia sexual ha renunciado al placer parcial o al que procura el acto de la procreación, reemplaza tales fines por otro que 
presenta con ellos relaciones de origen, pero que ha cesado de ser sexual para hacerse social. Damos a este proceso el nombre de "sublimación", y efectuándolo así, nos adherimos a la opinión general que concede un valor más grande a los fines sociales que a los sexuales, considerando a estos últimos en el fondo, como egoístas. ${ }^{26}$

Es positiva la continencia sexual para que la energía libidinosa se encauce en producciones de un nivel propiamente humano. Lo que es válido para los célibes como para los casados. Pero esta afirmación que Freud la insertó en su teoría sobre la sexualidad humana constituye una realidad observada múltiples veces por padres y educadores al comprobar que jóvenes dados al estudio, con excelentes rendimientos, tuercen estas trayectorias y se muestran incapaces para avanzar o abandonan los estudios cuando la pasión de la carne se apropia y se enseñorea sobre la voluntad de cada uno de ellos.

Herbert Marcuse (1898-1979), filósofo y sociólogo de origen alemán y una de las principales figuras de la primera generación de la Escuela de Frankfurt, observó en su libro "El hombre unidimensional" (Boston, 1964) que ese hombre surgido de la sociedad capitalista industrial moderna, conducido por una élite dominante ha "desublimado" y reducido a genitalidad el instinto libidinoso. Mediante el proceso que llamó "desublimación represiva" ha conseguido que la gente ahíta de placer abandone sus ideales, no tenga pensamiento propio, se aborregue y muestre una penosa sumisión al poder, un poder camuflado que le dirige y hace de los hombres meros peleles.

No se sabe aún, y difícilmente se sabrá en un futuro, si para hallar la verdad se cuenta tan solo con la metodología científica, qué relación puede existir entre la continencia sexual y el enriquecimiento espiritual, o dicho de otra forma: ¿hasta qué punto el "deseo" y el "placer voluptuoso" que proceden del estrato inferior de la personalidad extienden su influencia al resto de la misma? En la respuesta a esta cuestión surgirá la división y eso obliga a otra nueva pregunta: ¿Por qué motivaciones profundas, seguramente inconscientes, los hombres se adherirán a criterios distintos?

${ }^{26}$ Freud, Sigmund, Obras completas. Introducción al Psicoanálisis.II, Ed. Biblioteca Nueva. Madrid. 1968. p. 329. 


\section{b) Dependencia de los placeres voluptuosos y orgásmicos}

Según se ha explicado, la multiplicación de los actos propios del matrimonio puede abocar a un trastorno psíquico reconocido por la Psiquiatría con el nombre de "adicción al sexo". El reconocimiento de esta patología se ha producido por la severidad de la sintomatología de los afectados y por la necesidad de tratamientos en clínicas especializadas. También ha contribuido a su divulgación la confesión hecha por famosos personajes del cine y de la televisión, que la han padecido, en un elogiable intento de prevenirla. Sin embargo, hay muchas más adicciones al sexo no denunciadas de las que tan solo se mencionarán en este trabajo las referidas a la cópula hombre-mujer, dentro o fuera del marco matrimonial.

Son hechos conocidos que igual el hombre como la mujer, observando las debidas precauciones pueden permanecer vírgenes hasta el matrimonio sin grandes apuros. Del mismo modo muchas personas consagradas a Dios, de ambos sexos, con votos de castidad, permanecen continentes a lo largo de toda la vida hasta la muerte. Destaca el hecho, de fácil comprobación, de personas vírgenes que tras el matrimonio con extrema dificultad pueden permanecer sin una actividad sexual de periodicidad variable. ¡Cuántos matrimonios son incapaces de mantenerse continentes en los días fértiles del periodo! Igual hay que decir de los jóvenes castos que un día deciden probar o experimentar el acto hasta su consumación y a partir de entonces se sienten coaccionados por sus propios impulsos a seguir realizándolo. Ocurre que, de acuerdo con el popular dicho "quien lo prueba repite", el coito crea adicción, e igual ocurre en las múltiples prácticas sexuales, de cuyo comentario se prescinde. Es una adicción no reconocida en Medicina, a diferencia de otras muchas que se reconocen, como la del tabaco, café, analgésicos, tranquilizantes, somníferos, drogas de todo tipo, estimulantes, compras, uso de la televisión, de internet, ejercicio físico, etc. etc. La adicción al coito no se ha aceptado por la sociedad, ni es de esperar que se haga, porque esta práctica se considera una necesidad del ser humano, análoga a la comida, bebida, sueño y otras necesidades básicas del hombre. Craso error, porque hay necesidades que si no se satisfacen acarrean la enfermedad y muerte, mientras que la abstinencia sexual no provoca enfermedad alguna y hace al hombre más libre, sin sujeción a la atadura de la carne. 


\section{c) La posibilidad de copular sin placer voluptuoso}

¿Quién osará negar que el acto conyugal se rige por la pasión? Cualquier sexólogo podría muy bien calificar de perogrullada esta afirmación. Todo acto sexual hombre-mujer, sea dentro o fuera del matrimonio, obedece a pulsiones que surgen de las distintas capas del psiquismo y se desarrolla de acuerdo con unas fases ya descritas a mediados del siglo pasado, con fuerte protagonismo del "placer voluptuoso" en la fase denominada de "excitación".

Según san Agustín, de no haber pecado, nuestros primeros padres, ellos y su descendencia habrían engendrado sin la pasión propia de la concupiscencia. ¿Cómo habría sido posible? ¿Acaso el placer concupiscente voluptuoso no es el que excita los genitales y los prepara para que el coito pueda realizarse? ¿Acaso los sexólogos no enseñan técnicas para provocar la excitación sexual?

Los conocimientos actuales en psico-anatomo-fisiología humana, sobre todo tras la descripción de punto G a finales de 1940 por el exiliado alemán Ernst Gräfenberg y el estadounidense Robert Dickinson que repararon en una zona de especial sensibilidad erógena, situada en la superficie suburetral del muro vaginal anterior, hace muy improbable la hipótesis de que en un principio se pudiera realizar el acto procreativo sin el preceptivo recorrido por las fases de excitación y orgasmo. En el siglo presente las investigaciones continúan y se ha señalado el "punto G" formando parte del eje interno de la vagina y el clítoris, como responsable de los orgasmos femeninos.

A pesar de todo lo investigado en el momento actual nada hay concluyente que impida pensar que el acto conyugal pueda ser realizado sin el "placer voluptuoso", o con una mínima participación de él, pues la falta de este placer quedaría compensada con el incremento del "deleite por atracción" que tiende a concertar el acoplamiento físico del hombre con la mujer con un sentimiento íntimo y profundo de unión. No es en absoluto descartable la posibilidad de una actividad sexual en el matrimonio limpia de todo tipo de voluptuosidad que, para el obispo de Hipona, en un principio existió antes de la "caída" de nuestros primeros padres. De hecho, muchos matrimonios pueden referir actos sexuales con bajos grados de voluptuosidad, mencionados como "muy puros", "naturales", "gozosos" en su realización, a diferencia de otros realizados de forma 
vergonzosa o con recursos a todo tipo de imaginaciones obscenas y prácticas anti-natura. Por último, para explicar la posibilidad de una sexualidad intachable en el Paraíso quizás lo más simple sea pensar que en aquel estado de gracia preternatural los actos sexuales se desplegaran siguiendo las fases ya conocidas, pero sin que Adán ni Eva repararan en los placeres, dado que ellos valoraban tan solo su enlace en comunión. Algo muy distinto a lo que sobrevendría después.

\section{SAN AGUSTÍN OBVIÓ ALGUNOS SUPUESTOS DEL ACTO MATRIMONIAL}

\section{1. ¿Es el acto sexual conyugal una expresión de amor?}

\section{a) Filosofía personalista y acto conyugal}

Con la llegada del siglo XX escritores como Herbert Doms y Bernard Krempel, en una línea personalista, procuraron subrayar el valor humano de la cópula matrimonial como expresión del amor entre los esposos, y esta unión física, esencia del matrimonio, que se justifica por sí misma, tendría como finalidad, más importante que la procreación, la realización de los esposos en cuanto personas. Estas ideas fueron aceptadas por los nuevos teólogos, ávidos de innovaciones. Desde esta nueva perspectiva, la concepción del hijo, expresión de amor entre los esposos, seguiría siendo una finalidad del matrimonio, pero tan solo una más, y el remedio de la concupiscencia se eliminaría, en razón a la nueva valoración que se hace del apetito carnal.

En la encíclica "Familiaris consortio" de Juan Pablo II (2a parte, 11$)$ se puede leer:

En consecuencia, la sexualidad, mediante la cual el hombre y la mujer se dan uno a otro con los actos propios y exclusivos de los esposos, no es algo puramente biológico, sino que afecta al núcleo íntimo de la persona humana en cuanto tal. Ella se realiza de modo verdaderamente humano, solamente cuando es parte integral del amor con el que el hombre y la mujer se comprometen totalmente entre sí hasta la muerte. La donación física total sería un engaño si no fuese signo y fruto de una donación en la que está presente toda la persona, incluso en su dimensión temporal; si la 
persona se reservase algo o la posibilidad de decidir de otra manera en orden al futuro, ya no se donaría totalmente.

Tras el Concilio Vaticano II se ha aceptado que el acto matrimonial es una expresión de amor entre los esposos y el placer que experimentan en dicho acto una recompensa que Dios ha querido otorgarles por practicar algo querido por Él. Esta visión es diametralmente distinta a la de San Agustín y merece ser analizada. Y puesto que el vocablo amor es sumamente equívoco se hace necesario unas primeras consideraciones.

La idea directriz es igual a la ya conocida desde la constitución apostólica “Gaudiun et Spes", inspirada por Juan Pablo II, y resulta interesante porque muestra que se ha formado escuela, e interpretar el acto sexual como una expresión de amor, en el que se entregan generosamente los esposos, el uno al otro, se convierte en un concepto básico que habrán de aprender todos aquellos que aspiren a desarrollar cualquier actividad en el círculo eclesial dedicado a la familia.

\section{b) Amor erótico. Amor benevolente. Cariño}

La Psicología Social actual reconoce una gran variedad de tipos diferentes de amor, siendo común a todos ellos que comportan un cálido sentimiento hacia el ser amado y una tendencia a procurarle el bien. Como afirmaba Aristóteles amar es querer el bien del otro en cuanto otro. Dentro de la diversidad valora especialmente dos de ellos, que tienen remembranzas medievales y escolásticas. Se trata del amor erótico y el amor agápico, ya descritos en el siglo XIII por santo Tomás de Aquino que llamó "amor concupiscente" y "amor benevolente", a dos tipos diferentes de amor que se correspondían con los conceptos clásicos griegos de Eros y Ágape.

a) El amor que existe entre un hombre y una mujer unidos en matrimonio, gracias a su condición de seres sexuados que se atraen, es en primer lugar amor erótico, pero este tipo de amor no excluye el amor altruista o ágape, ni el simple cariño. El amor erótico brota de la complacencia y placer que como ser sexuado una persona recibe y proporciona a otra. Es un sentimiento que surge en exclusiva hacia el ser que proporciona placer sexual, sea del tipo que sea. Se quiere a ese tú en tanto es fuente de placer, y mientras el placer se ofrezca,.. porque si la fuente se seca el amor desaparece. El pintor Pablo Picasso amaba a la mujer-compañera en tanto ella 
le cautivaba por su juventud y belleza, pero la sustituía por otra cuando el placer declinaba. Por eso afirmaba que para él las mujeres eran de dos clases: "las diosas y las que son como felpudos"27.

b) Amor agápico o benevolente. Inicialmente, ágape fue un término de origen griego (agapé) con que se expresaba el amor, la amistad y las comidas en común. Posteriormente los primitivos cristianos lo emplearon para denominar las celebraciones con una comida colectiva, a fin de avivar y exteriorizar la caridad mutua, o incluso para referirse a la celebración de la Eucaristía. El término se identificó finalmente con el ideal cristiano del amor, o caridad, entendido como altruismo, abnegación, entrega y dedicación totalmente desinteresada al prójimo, y con este significado persiste en nuestros días. Es el amor que se debe tener hacia toda persona, que por el simple hecho de serlo merece ser amada, pero si esa persona es el cónyuge, razón de más para amarla, con independencia a su edad, salud, belleza, y demás rasgos individuales. La diferencia con el amor erótico que se centra exclusivamente en un tú es evidente, pues no se fundamenta en las bellas cualidades personales, ni en los beneficios que proporciona, sino en la "capacidad de amar" propia, que cada cual posee y proyecta sobre un prójimo cualquiera, sin distinción alguna. Es un amor proporcional a la dimensión espiritual de cada uno; es gracia que se recibe de Dios y se manifiesta de múltiples formas mediante una conducta bondadosa dirigida a todo el mundo.

c) A los dos tipos anteriores de amor se les puede añadir un tercero con el nombre de filia, cariño, amor de amigo y también con el término griego storge. Es el afecto que se da entre familiares, amigos, y compañeros. Es un sentimiento de afecto que surge hacia una persona, provocado por la amistad, el trato asiduo, el desarrollo de una especial intimidad o la simple convivencia, cuando abunda la humanidad, simpatía, sinceridad, comprensión, la ayuda mutua y tolerancia. Incluye sentimientos variados, próximos entre sí como el apego, aprecio, gratitud, etc. El desafecto como sentimiento opuesto al cariño surge igualmente de experiencias previas penosas, tediosas, irritantes, desagradables, repulsivas, etc.

Ante la pregunta sobre si el amor, en cualquiera de sus modalidades, conduce al acto sexual, la respuesta es no. Lo que conduce al acto sexual

${ }^{27}$ Gilot, F. Y LaKe, C. Vida con Picasso. Ed. Elba. Barcelona. 2017. p. 129. 
es la pasión voluptuosa y la atracción erótica, sin ellas, especialmente de la segunda, cualquier acto sexual en la pareja, por muy unida que esté, será defectuoso o nulo. El amor surge como efecto, es consecuencia; ni provoca ni está presente en el curso de la función que terminará en orgasmo. En ese trance las dos partes se permitirán buscar con ansia en la pareja todo lo que satisfaga sus impulsos libidinosos.

Desde el s. XII, cuando nace el "amor cortés" en la corte de Leonor de Aquitania, el romanticismo amoroso ha ido extendiéndose progresivamente por los países occidentales, apoyado por la literatura y el teatro, hasta llegar a nuestros días, en el que tiene plena vigencia. Por eso se acepta sin reparo alguno que cuando existe un fuerte enamoramiento en una pareja, la fuerza de su amor le impulsa a la más íntima unión de sus cuerpos y almas. En realidad, lo que ocurre es que si se aman con locura es porque la atracción, el "deleite por atracción" es muy intenso, y se constituye en el origen de su amor, y es este deleite el que les induce a disfrutarlo en plenitud, mediante la cópula. No es el amor el inductor sino la atracción erótica.

Dado que el acto sexual se desarrolla en el ámbito matrimonial en el que debe reinar una atmósfera de amor, síntesis de los tres amores mencionados, se ha dicho y admitido en los círculos eclesiales que ese acto, el "mal permitido" de san Agustín, es una expresión de amor conyugal, en el que marido y mujer se dan mutuamente: "la sexualidad, mediante la cual el hombre y la mujer se dan uno a otro con los actos propios y exclusivos de los esposos, no es algo puramente biológico, sino que afecta al núcleo íntimo de la persona humana en cuanto tal". Escribió Juan Pablo II en "Familiaris consortio" ( $2^{a}$ parte, 11). Ese "darse" ha sido interpretado como prueba generosa de amor, de forma similar al regalo que una madre podría recibir de un hijo el día de su cumpleaños. Pero en el matrimonio, en el que efectivamente marido y mujer "se dan", la interpretación debe ser bien distinta. Los cónyuges se ofrecen mutuamente, y eso supone vencer el pudor, no por la fuerza del amor, sino por la fuerza de los impulsos de la libido que a ello les obliga. Además, el coito es placer que reciben ambas partes y la contribución es idéntica y acompasada del hombre y la mujer.

$\mathrm{El}$ amor altruista y desinteresado no es el motor que conduce al acto conyugal. Pero la conducta sexual conyugal se desarrolla en un medio familiar querido por Dios, en el que los esposos están obligados a quererse hasta la muerte, a tener hijos y a educarlos, por todo ello no se puede igua- 
lar la dignidad de esta conducta a la que se desarrolla fuera del matrimonio, sean novios, amantes, amigos o entre personas que no mantienen entre sí ningún tipo de relación.

La filia, cariño o amor de amigo exige a los cónyuges para su acrecentamiento cuidarlo con mimo, día a día, evitando todo aquello que incomoda al otro y multiplicando las atenciones con gran esmero para hacer de la convivencia un auténtico hogar, donde todos los miembros de la familia encuentren el espacio cálido y acogedor, adecuado para desarrollarse lo mejor posible como personas. Sin duda, que el cariño entre los esposos facilita su aproximación afectiva y los actos propios reservados al matrimonio. Este afecto junto al amor agápico influye para que los esposos en sus momentos de intimidad actúen con delicadeza y sepan disculpar los momentos de indisposición que impiden las expresiones eróticas. Las coacciones, violencias, cualquier tipo de maltrato, no se entienden si el amor en sus distintas modalidades o en todas ellas preside la vida matrimonial, pero los actos sexuales en sí mismos considerados obedecen a otro tipo de razones.

El santo obispo de Hipona cuando trató de la sexualidad matrimonial no hizo alusión al amor como principio inclusivo a los actos que le son propios, y nada hay que reprocharle puesto que, como ha quedado expuesto, el amor en sus diversas modalidades no participa de forma significativa en ellos. Otros supuestos distintos serán objeto de reflexión.

\section{Sobre el efecto unitivo del acto conyugal}

Muchas de las ideas del movimiento filosófico personalista creado por el pensador católico francés Emmanuel Mounier (1905-1950), fueron recogidas por importantes teólogos con anterioridad al Concilio Vaticano II y luego se transmitieron a documentos conciliares y han forjado una antropología católica muy extendida en la actualidad. Uno de estos teólogos fue el suizo Hans Urs von Baltasar (1905-1988), que se refirió a la unidad dual hombre-mujer como seres definidos por su incompletud, una idea compartida por otras importantes figuras eclesiales, que encuentra un antecedente lejano en el mito del andrógino que se puede leer en "El Banquete" de Platón. ${ }^{28}$

${ }^{28}$ Aristófanes, tomando la palabra define al amor como a "un íntimo anhelo de restitución de una plenitud perdida, de reencuentro con un total”. Contó que en la antigüedad, 
La soledad que siente el célibe, religioso o no, similar a la del viudo, y esto vale para los dos sexos, tiene su peculiaridad. Es una soledad profunda, no mitigada por una convivencia con familiares íntimos, del tipo de los padres, hijos, o hermanos, ni por vivir en comunidades civiles o religiosas con amigos o compañeros. La atracción sexual no concretada en un tú, encuentra en esta soledad originaria un nexo de recíproca relación. Ambas se manifiestan vivencialmente como una queja, un dolor, una necesidad a satisfacer, un remedio común a ambas, que no es otro que el compañero sexual.

Karol Wojtyla criticó la visión hostil dirigida hacia la sexualidad, mantenida durante veinte siglos, y quiso sustituirla (en el afán renovador que presidió el Concilio) por otra bien distinta, que años antes ya había concebido, y que, una vez expuesta, tuvo muy buena acogida entre los padres conciliares y posteriormente ha presidido el pensamiento católico hasta el momento presente. En su libro "Amor y responsabilidad", afirmó que la teología católica solo ha visto una "tea" de pecado, es decir, una ocasión de pecar, en tanto nos predispone, a causa del pecado original, a "desear" el placer "utilizando" al otro en lugar de amarle. El amor matrimonial, para él, es un amor que surge de una necesidad que se busca y se necesita ${ }^{29}$, como bien del que cada sexo carece. Y para que sea verdadero amor, la persona que desea a otra ha de quererle un bien, es decir debe amarle, igualmente, con benevolencia, y de esta forma encuentra una conexión entre los dos tipos de amores: el erótico y el agápico. Si no ocurriera así, el simple deseo dejaría de ser amor y se traduciría únicamente en egoísmo.

Angelo Scola (Malgrate, 1941), cardenal italiano, arzobispo de Milán, se ha referido a "la soledad originaria del hombre", también estudiada por Wojtyla, y afirma que es debida a su naturaleza, y que al descubrir en

\footnotetext{
la humanidad se dividía en tres géneros, el masculino, el femenino, y el andrógino (del griego Andros-Hombre y Gino-Mujer). Los seres que pertenecían a esta última clase eran redondos, con cuatro brazos, cuatro piernas, dos caras en la cabeza y, por supuesto dos órganos sexuales. Zeus los castigó partiéndolos por la mitad y Apolo los curó dándoles la forma actual que tienen ambos sexos, desde entonces el amor trata de unirlos, de manera que, cuando se encuentran se unen para toda la vida, tratando cada uno de reunirse y fundirse con el amado y convertirse de dos seres en uno solo, de manera que tan solo podría alcanzar la felicidad nuestra especie cuando se dé el tiempo en que la mitad de la Humanidad se encuentre con su otra mitad.
}

${ }^{29}$ Wojtyla, Karol, Amor y responsabilidad. Ed. Razón y Fe. Madrid. 1979. PP. 84-85. 
su cuerpo los signos de su sexualidad masculina encuentra el camino para salir de su soledad, mediante la comunión con la mujer. Afirmó, apoyándose en H. von Baltasar, que la distinción de los dos sexos forma parte de la original creación de Dios, de acuerdo con el relato del Génesis:“...y créo Dios al hombre a su imagen, a imagen de Dios lo creó, varón y hembra los creó." (Gn 1,26-27). De esta forma la polaridad hombre-mujer, en cuanto seres sexuados forma parte de la imagen de Dios.

Las anteriores ideas fueron asumidas por Pablo VI, que tras el Concilio supo expresarlas en la encíclica "Humanae vitae", 1968 (HV) con estas palabras:

Efectivamente, el acto conyugal, por su íntima estructura, mientras une profundamente a los esposos, los hace aptos para la generación de nuevas vidas, según las leyes inscritas en el ser mismo del hombre y de la mujer. Salvaguardando ambos aspectos esenciales, unitivo y procreador, el acto conyugal conserva íntegro el sentido de amor mutuo y verdadero y su ordenación a la altísima vocación del hombre a la paternidad. Nos pensamos que los hombres, en particular los de nuestro tiempo, se encuentran en grado de comprender el carácter profundamente razonable y humano de este principio fundamental (HV 12).

Dejar de sentir la soledad más profunda de las soledades y encontrar a una persona con la que compartir la vida para siempre por su atractivo sexuado, constituyen dos realidades que se anudan en inalterable trabazón, y alcanzan su momento vivencial culminante en el ayuntamiento carnal. Así es, en ese acto el hombre y la mujer íntimamente unidos, se perciben plenos, sienten que hay una persona capacitada para extinguir el sentimiento de incompletud. Momento dichoso y sublime, reservado por Dios para la trasmisión de una nueva vida. Pablo VI encontró dos significados y los dos inherentes al acto sexual, es decir, esenciales (que forman parte de su naturaleza), por utilizar una terminología filosófica: el primero es el unitivo, el segundo es el procreativo. El acto sexual une a dos personas de distinto sexo en el matrimonio. No une dos cuerpos, une a dos personas (en su totalidad psico-fisica-espiritual).

El efecto "unitivo" del acto sexual enunciado por el Papa permite alcanzar una mejor interpretación si se encuadra en una concepción como la expuesta en este trabajo: en el que se reconoce la importancia del "deleite de atracción" que anima a la pareja a fundirse, a unirse íntimamente 
con un tú, hacia el que se siente una especial seducción. ¿Es una finalidad "esencial", el efecto unitivo del acto sexual? ¿Forma parte el fin unitivo de la naturaleza del acto sexual? Siguiendo la doctrina de Tomás de Aquino que distinguía en el matrimonio fines esenciales y fines accidentales, el "significado unitivo", que ha de ser interpretado como la consumación de la atracción intersexual, pertenece a los fines esenciales, en tanto forma parte de la naturaleza del acto sexual dentro del matrimonio.

La excelencia del efecto unitivo es propia de la cópula matrimonial, cuando cada cónyuge así mismo se dice: "ella es mi mujer", "él es mi marido", "estamos unidos por Dios para siempre". No ocurre igual en otros acoplamientos ajenos al matrimonio. Pues, ¿cómo sería posible sentirse unido a quien se presenta como ave de paso o por un tiempo de duración incierta? Por grande que sea la atracción erótica si no se da el sentimiento de pertenencia mutua y para siempre propio del matrimonio el efecto unitivo no se producirá en su integridad. Quienes participan de una coyunda no legitimada llorarán en su interior por la falta de un compromiso nupcial previo, aunque también pueden sentir la urgencia de realizarlo cuanto antes.

San Agustín no se percató de la finalidad unitiva del acto conyugal, lo que implica ignorar la presencia del noble "deleite de atracción" en múltiples manifestaciones sexuales, constituido en principal protagonista, muy por encima de cualquier leve voluptuosidad. Creyó en una sexualidad primera no tocada por el pecado corruptor de nuestros primeros padres, pero ¿cómo se habría podido desenvolver sin que el "deleite" desempeñara un relevante papel? Teólogos de nuestro tiempo, entre ellos Hans Urs von Baltasar, han echado en falta la existencia de parvedad en las faltas sexuales, pues aquí se les ofrece un argumento a esgrimir.

\section{CONCLUSIONES}

El análisis de los tres tipos principales de placeres que concurren en el acto sexual conyugal: "deleite por atracción”, "placer voluptuoso" y "placer orgásmico", según denominación propia, permite alcanzar una nueva comprensión del mismo. Se comprueba que el santo obispo no estaba equivocado cuando denunciaba que en la cópula matrimonial "hay un mal", porque efectivamente lo hay. 
1. El "placer voluptuoso" lleva en sí un apremio que hace difícil su dominio por la voluntad. Además, exige unos estímulos que, de forma similar a las adicciones, requieren su incremento y ser cambiados por otros nuevos, lo que conduce, si no media la debida templanza, a muchos desórdenes y a la enfermedad conocida como "adicción al sexo".

2. El acto sexual de por sí es adictivo, aunque no se le considera esta condición cuando se practica con una frecuencia moderada y dentro del ámbito matrimonial.

3. La posibilidad enunciada por el santo obispo, de haber existido una sexualidad conyugal previa a la caída de nuestros primeros padres en el pecado, distinta y mas noble a la conocida, se hace accesible, con los conocimientos psico-anatómicos actuales y con fundamento en el "deleite por atracción", hasta ahora el gran olvidado en el estudio de la sexualidad humana.

4. Se deslindan los tres tipos principales de amor relacionados supuestamente con el acto sexual: amor erótico o concupiscente, amor agápico o benevolente y amor amigo o filia.

5. Ninguno de los tres participa como agente activo en el coito, que desde el inicio hasta su conclusión es sacudido por los impulsos voluptuosos y los de la atracción erótica. Los primeros de carácter apremiante y los segundos reposados. Consecuencia del placer disfrutado surge el amor erótico, como efecto, no como causa, un amor egoísta que aspira a la retención para sí del ser querido. El amor agápico permite el desarrollo del acto sexual sin maltrato ni violencia y el amor amigo facilita los encuentros sexuales.

6. El fin unitivo del acto sexual no fue contemplado por san Agustín, un hallazgo de la filosofía personalista que fue muy bien acogido por figuras de la Iglesia que tendrán gran protagonismo durante y después del Concilio. Pablo VI en su famosa encíclica "Humane Vitae", aunque reconoció dos significados en el acto sexual, el procreativo y el unitivo, no llegó a percibir que este último supone la culminación de los impulsos implícitos en el "deleite de atracción".

7. Al santo obispo de Hipona hay que otorgarle un gran mérito en su análisis de la actividad sexual en el matrimonio, a pesar de no 
haber reparado en fuerzas nobles que impulsan a la unión íntima de los esposos. Pero en cambio:

- Reconoció que en el acto matrimonial hay un mal.

- Acertó al no mencionar el amor en los actos conyugales puesto que son actos que se despliegan bajo el impulso de fuerzas ajenas a este sentimiento.

- Creyó en una sexualidad edénica que pudo existir en un principio y luego se depravó.

Cuando determinados capítulos de la obra agustiniana han sido silenciados después del último concilio ecuménico y se contradicen de forma encubierta o explícita juicios del "Doctor de la Gracia", importa señalar que por más que en el presente ensayo, se hayan hecho valoraciones desafectadas eso no significa subestimar la figura y obra del obispo africano que ha de seguir siendo luminaria para bien de la Humanidad. 